\title{
THE ANGLO-AMERICAN OIL AGREEMENT
}

\author{
HERBERT FEIS $\dagger$
}

I

\section{The Shaping Circumstances}

THE Anglo-American oil agreement was a tardy and groping expression of the wish of the American government to assure the adequacy of our future oil supplies. Twice attempts were made to achieve this end by independent national action. Only after they failed did thought turn towards an international arrangement.

The reasons for our concern were plain. During the war the United States consumed oil at a gigantic rate - to sustain life and production within the United States, to supply American fighting forces abroad, and to satisfy the needs of our allies. The rate of use substantially exceeded the amount of current proven new discoveries within the United States. Fear spread that the reserves of the United States (and of the rest of the hemisphere) might not be sufficient for future needs; needs which, experience showed, might be tremendous in the event of another war. Nations that lacked oil had to bargain or barter for it; they became dependent on the will or bounty of others; the United States was unused to the idea. Both our security and our independence in these hours of swift anxiety seemed threatened. The Petroleum Administrator for War brought these fears to public attention when, with a doubting turn of phrase, he posed the direct question as to whether we should be able to "oil another war."

Appraisals of the situation were tinged by resentment because the resources controlled by British companies were not being drawn upon equally; the geography and logistics of the war made it impossible to do so. And ideas regarding our possible future need, evoked by the experience of a navy fighting over the seven seas, became roving and far-flung; they stretched out into a wish for certainty that there would always be an assured and near source of supply for our ships whenever and wherever a battle could best be fought.

In the atmosphere of sudden alarm, the reassuring aspects of our situation were not carefully reckoned. Many prognosticators too quickly concluded that the then current lag in new discovery within the United States was of permanent significance. At the same time pessimism spread in regard to the reliability of supplies drawn from the Caribbean area. The rude expropriations of American interests that

$\dagger$ Economic adviser to Department of State since 1931; adviser on international affairs 1937-1943; chief technical adviser on the American delegation to the World Economic and Monetary Conference, London, 1933; adviser on the American delegation to the Conferences of American Republics at Buenos Aires, 1936; Lima, 1938; and Panama, 1939; special adviser to the Secretary of War, 1945-46. 
had taken place in Mexico and Bolivia, the attempts of Argentina to squeeze out the American interests active there, the refusal of Brazil to admit foreign interests, the stiffening terms asked by Colombia and Venezuela-all these made the American industry doubtful about the security and profitability of their ventures in Latin America. The industry was willing to gamble mightily on the secrets of nature; it had usually come out a winner in that game. But it lacked equanimity in the face of governments which could, if they insisted, have the last say on the rules.

The possibilities of synthetic production were established but not attractive; they would require an immense new investment and the product would be more costly.

These reckonings combined to direct attention to the one other vast supply of oil still awaiting the drill - the Arab lands of the Middle East. The concept of American isolation had crumbled. Upon its ruins the idea was sprouting that, thenceforth, to be secure, the United States would have to concern itself with the affairs of every part of the world. The Middle East offered an attractive and effective base of operation-economic, political and military-to minds that were feeling the elation of our power. And the American oil companies already located in that area were eager for support and assistance since they felt themselves obstructed by circumstance and beset by risks, while oil enterprises in other areas were pushing forward operations at a tremendous rate.

The Standard Oil Company of California and the Texas Company possessed in partnership an exclusive right to develop the most promising fields of Saudi Arabia and the smaller field located on the nearby island of Bahrein. The Gulf Oil Company held a half partnership with the Anglo-Iranian Oil Company in oil that might be produced in the neighboring sheikdom of Kuwait, but it was restricted by an agreement not to market its share of the products in countries already served by its partner. Production in Saudi Arabia and Bahrein had barely begun when the United States entered the war. The first period of exploration and construction was just coming to an end, and the assured profitable markets for this oil had up to then been small. Now the companies, having made considerable investment, were eager to expand production but half afraid to do so.

They feared first of all for the safety of their concessions. This was in part a fear that British influence would be used to sway local governments to make oppressive demands. They were also afraid that the extension of Russian ambitions towards the Persian Gulf might disturb or dispossess them. They feared that they might, sometime or other, become involved in local disputes over political power-not with Ibn Saud who had granted the concessions, but with his heirs or rivals. They feared that they might not be able to sell profitably large quan- 
tities of production in competition with other Middle Eastern producers-especially in foreign markets subject to exchange control or discriminatory restrictions. Finally, they feared that if oil production did not bring large enough royalties to local sovereigns, incalculably large advances would be demanded of them.

By the American government, disturbed over the future oil outlook, the continuance of American control over these Middle Eastern concessions was now accepted as vital. During war, only those sources of supply which were under complete command, economic and military, seemed certain and satisfactory. The question of whether and how the United States could be certain of retaining control of, and access to, Middle Eastern sources of supply under the circumstances of future emergency was not fully explored. That would depend on who our friends and enemies turned out to be, where the fighting was, and what the weapons. Judgment took the customary route of national calculation that the retention of American control was a clearly advisable precaution; there would be time later to figure out how these oil fields could be protected and used in the event of war.

Furthermore, the Middle Eastern oil fields could immediately serve our armed forces in the Pacific, saving time and transport, and lessening the current drain on the reserves of this hemisphere. They could become a permanent source of supply to American (and possibly foreign) oil companies engaged in distribution in the Far East, the Mediterranean, and Europe, thus reducing the future rate of use of American reserves. These fields could also be an ample and cheap provider for our navy and air force during peace time. It therefore was judged clearly advantageous, if not essential, to hasten the expansion of production in all the Middle Eastern oil areas.

About the time these ideas matured in official circles, American oil companies without Middle Eastern oil holdings sought to crowd in next to the established enterprises-as usually happens when a great new oil region is discovered within the United States. Two large companies sent representatives to Iran to bid for concessions in the sections of that country not included in the Anglo-Iranian concession, while others probed Egypt. And the American partners in the Iraq Petroleum Company (with large production in Iraq) persuaded their foreign partners (who took little persuasion) to hurry with plans for a second pipeline to the Mediterranean. All these activities were favorably regarded by the United States as contributing towards adequate supply during the war and thereafter.

\section{The First Atrempted Measures}

These circumstances and purposes prompted the American government in the years 1943-44 to make two bold and independent attempts to assure the American oil position in the Middle East. 
It tried first to buy the capital stock of the Arabian-American Company (which owns the concessions for Saudi Arabia) and the Bahrein Petroleum Company (which owns the concessions for Bahrein). The parent American oil companies refused to sell.

Next it entered into an agreement with these companies whereby the government undertook to construct a pipe-line from the main proven fields along the Persian Gulf to the Miediterranean. This pipeline would have substantially reduced the cost of transport, and thereby enabled Arabian oil to compete in the markets of Europe and the Mediterranean with oil from other parts of the Middle East and the Western hemisphere. This project also was defeated. Liberals condemned it as a dangerous, if not a sinister, leap into imperialism. Isolationists condemned it as placing the American government in the middle of the struggle between the British Empire and the U.S.S.R. for dominance in the Middle East.

And most decisive of all, virtually all sections of the American oil industry rose up in protest. Neither measured in their views nor restrained in their expressions, they united in opposition to an arrangement which, according to their expressed belief, might place the government in competition with them all, everywhere. The domestic producers feared that the step might prepare the way for an increased importation of oil into the United States. The American oil companies engaged in production in the Caribbean (who then were spending great new sums to expand production) feared that it would mean loss of foreign markets. The American participants in Iraq production felt that the government was favoring their immediate business rivals.

American opposition was so vocal and vigorous that foreign interests and governments did not have to indicate their attitudes. They were free to sit by and marvel at the exuberance of our internal row. The project was permitted to die in an unreal international silence.

But the anxieties and aims which had impelled the American government's activities remained. How could continued American control of these oil fields in the Middle East be protected? How could the production of Middle Eastern oil be rapidly increased? How could fair and equal opportunity for American oil enterprise in those parts of the Middle East still open to search be assured? The government remained unwilling to trust to ordinary economic incentives and the usual forms of diplomatic protection.

\section{The American Approach to the Agreement}

After the failure of national action, the thought took root that the situation and future prospects could be managed by international agreement. The United States, whose nationals held a commanding place in oil development and possessed great resources, had much to 
offer other nations, and nothing that it sought could be fairly judged as harmful, unjust or threatening to them. Could not our aims and those of others be embraced in a joint program - a program that would simultaneously protect the future American position, avert or soften rivalries, and reconcile the interests of producing and dependent countries?

Such were the hopeful thoughts that shaped the first proposals for an international agreement. The attitude of other governments was unknown. And there lurked in the background unsettled questions of relationship between the government and the oil companies.

The oil companies were independent and suspicious. Governments, particularly the American government, might persuade but could not control them. This imposed a serious limit on the obligations which our government could accept. But in another aspect it provided a healthy restraint. The necessity for respecting private interests might be a safeguard against excessive or unfair foreign demands. There was a genuine risk in inviting undisciplined national governments to intervene in this vast international activity. If they were unscrupulous and at odds with one another, they might chain or smash it. They were, on the whole, more likely to quarrel than the oil companies and less likely to compromise. What was wanted of national governments was a firm promise that they would behave reasonably and decently if the oil companies did.

It seemed advisable to move with caution. The best way to find out what kind of international agreement, if any, was possible seemed to be to discuss the matter first with the country whose interest in oil seemed most similar to that of the United States-Great Britain. Moreover, the problems of rivalry in the Middle East, which were then in the forefront, seemed mainly to be between us and the British.

For these reasons the attempt to formulate an international oil agreement was restricted to discussions between the American and the British governments. This may have been a mistake. No one will ever know what would have happened had a more comprehensive group, including the U.S.S.R., been invited into these first conferences.

The ideas that the American representatives upheld were a mixture of national aims (based on the thought that the United States would have to take care of itself) and international purposes (based on the wish to advance the prospects of peace-economic and political). The government wished to assure the adequacy and certainty of supplies available to the United States; therefore it wished to safeguard the opportunities already held by American enterprise. But it was eager to avert dispute over the great remaining opportunities and was predisposed to favor dividing them in order to avoid unlimited diplomatic and economic contest.

The government recognized the right of each country to decide 
whether and on what terms to admit foreign oil enterprise within its borders, but it was hopeful that countries could be persuaded that it was to their advantage to open the door. It recognized the validity of the claim of countries of source to a generous share of the economic returns from oil produced within their borders. It farored the view that companies engaged in the international oil business had an obligation to provide oil to all countries on equal terms.

It had no intention of using its control over supply as a weapon of national policy in time of peace. And after the war control over oil supply might be deemed of less military importance. The war partnership that was defeating the Axis would, it was hoped, continue afterward. In that event the need for national precaution would become less intense, and co-operation in a collective security organization might become the primary line of defense. It might then be possible to contemplate the gradual establishment of international regulation of oil operations everywhere.

\section{II}

\section{The Negotiation of the Agreejent}

The British delegation to the conference was compact and experienced. Headed by a senior civil servant, it included executive officials of the two enormous British oil enterprises that operate in foreign lands. There was every sign that the British government and British industry were in agreement as to what they should seek and what they should grant. By contrast the American delegation was very large and divided within itself. The two senior government members (Secretary of State and Petroleum Administrator for War) were not at ease with each other. Several of the great American oil companies with foreign interests had been invited to share in the conferences as advisers. But as the meetings proceeded they became dissatisfied with their part. They felt themselves treated as outsiders. Each was afraid that some other oil interest would fare better than the one he represented, and all were afraid that the agreement would handicap the industry rather than help it. Despite these difficulties the main outline of an agreement was eventually created, and remaining details were subsequently settled by cable.

Not until another British delegation, headed by Lord Beaverbrook, Lord Privy Seal in Churchill's cabinet, came to the United States to conclude the compact did the true significance of the misunderstanding between the American government and the American oil industry during the conference become plain. The problems of relationship that had remained now became manifest in open argument. The industry rebelled at some of the proposed principles, fearing that it might become subject to government dictation. It wished to be sure that it would have an ample chance to pass judgment upon any significant 
attempt to apply the principles formulated in the accord. In the vague language and hideously entwined construction of the text, suspicious minds could find some justification for many fears.

These centered on three points. The first flowed from the fact that the State Department undertook to submit the agreement to Congress to be enacted as a Treaty. A weakly established doctrine circulates among international lawyers to the effect that if the government assumes an obligation in treaty form, it is free to ignore usual constitutional restraints in its enforcement. The industry feared that the executive branch of the government might use the vague language of the Treaty to regulate vital activities of the American oil industry, even the domestic activities. Some elements in the industry seemed convinced that this was the main purpose of the agreement.

The second fear of the industry was that, as an outcome of the agreement, the government would restrain or interfere with foreign operations; it might intervene in the search for or development of foreign concessions, perhaps dictate price policies, marketing arrangements and the like. The heads of the industry did not relish the possibility of sharing the rule of their vast empire.

The third fear was that the agreement would operate ultimately to favor increased imports of foreign oil into the United States. Since the original inspiration for the negotiation had been a wish to protect future American reserves, it was deemed likely that the American governmental representative on the International Petroleum Commission (which was to be established under the agreement) would not resist proposals that would further open the American market to foreign oil. Domestic producing interests on the whole do not share the opinion that our oil reserves will be insufficient for our future needs. They remain confident that, if the inducement to look for and produce oil is satisfactory, American production will long be adequate, at least for domestic needs. At all events, they do not wish to share the American market unless it is more plainly necessary that they do so.

Government officials were quick to recognize that they could not overcome this battery of fears and suspicions. The agreement was withdrawn from the Senate. Discussions with the industry were renewed regarding amendments that would make the agreement acceptable. After long and difficult argument, agreement was achieved. The British government and oil interests readily accepted the proposed changes. These did not lessen its possible value to them; for they left unaffected the prospect of harmonious action in defense of existing concessions in the Middle East and Caribbean. The revised agreement was signed in September 1945. Shortly thereafter it was re-submitted to the Senate.

There it languishes, half forgotten. The spasm of belief that the international differences of various shades over oil might be adjusted 
in accordance with jointly formulated principles seems to have spent itself for the time being. Apparently there is common consent to leave the proposal in dull suspense, while each country and each company proceeds with its own plans.

In part, this delay is a reflection of the change that has occurred in the oil supply situation since 1943-44, but it probably also results from a judgment that the agreement in its present form does not provide means of dealing with those events most likely to disturb the international oil situation; in fact, its enactment now, especially if coupled with new inter-governmental discussions, might increase the chances of disturbance.

The change in the oil supply situation has been comforting. Production within the United States and the Caribbean area is ample for current needs, and estimates of proven reserves have been revised upward. Production in all of the Middle Eastern fields has been expanding rapidly. American companies engaged in production in Saudi Arabia and Bahrein are greatly increasing their output, aided by navy contracts. They are proceeding with plans to construct a pipe-line to the Mediterranean when the commercial and political outlook becomes more secure. The Gulf Oil Company is preparing to develop greater production in Kuwait. In all, Middle Eastern oil is entering into the world's supply lines in far larger proportions than before the war. The discussions between the American and British oil companies themselves quieted mutual suspicions. The hypothesis that they could not work together has been superseded by a belief that they can.

Simultaneously with these pacifying changes of circumstance, signs of possible new troubles, more serious perhaps than those visualized in the past, have appeared. These emerge from political disputes. Oil is not their root, and settlements having to deal merely with oil will not dispose of them. The first arises from the struggle over Palestine which now involves all the Arab states. The second stems from the mistrust between the U.S.S.R. and the Western powers. No one knows how deep this may become or what regions it may affect. Should it persist, Middle Eastern oil may become a counter in the dangerous struggle.

The new manifestations of Russian interest in acquiring control of oil resources outside of its boundaries have raised the question whether an immediate effort should not be made to re-negotiate the Petroleum Agreement as a three- or four-party agreement. This would be feasible only if Russian aims in oil were similar to those of the United States and Great Britain and if the U.S.S.R. were willing to leave existing American and British interests undisturbed. Is there any chance of arriving at a common policy with the U.S.S.R. in oil until the more critical issues troubling the relations between the U.S.S.R. and the Western powers are settled?

These are the main reasons for the present inaction regarding the 
American-British agreement. As it now stands the agreement is a frail and filmy web of intention to which no country could take serious objection. Yet the agreement should be resuscitated to give clear proof of our willingness to abide by its amicable principles. It is a first step toward a more comprehensive and significant agreement if and when substantial harmony is reached on more basic issues.

\section{III}

\section{The Agreement}

The reader of the agreement is at first likely to feel as though he were walking among the spaces and angles of an abstract painting. It is hard to identify and sort out its contents, harder still to construe them.

The accord is bold in that it embraces oil activities not merely in the Middle East, but throughout the whole world. This would have many advantages, if achievable. The same general rules should be roughly applicable to international oil activities everywhere, to the extent that it is practicable. For one thing, oils produced in fields far distant from each other compete for the same market; those whose interests lie in any one particular source of supply are affected by policies and practices pursued elsewhere. Also, disputes between competing interests for oil reserves, or disputes between foreign interests and governments within whose territory oil resources lie, may arise anywhere. Therefore the wish to create an identical basis for the adjustment of such rivalries and disputes, no matter where they occur, was justified.

But an agreement of universal scope may be harder to obtain than one of regional scope; and any universal agreement obtainable is likely to be extremely broad and general in meaning. Take for example, the rule affirmed in the American-British agreement that "with regard to the acquisitions of exploration and development rights the principle of equal opportunity shall be respected." This may be satisfactory to the countries of the Middle East but unacceptable to some other countries in the Caribbean area, or, perhaps, China. Or take the rule that oil should be supplied to all countries on "competitive and equal" terms. This may be acceptable to certain companies operating in certain regions, but not acceptable to others elsewhere, who have built up their development plans on the basis of special contracts. For reasons of this type greater flexibility in interpretation and administration will be required, thereby accentuating one of the troublesome characteristics of the accord, its lack of precision.

So vague is the agreement that it is impossible to be certain as to the significance in practice of any of its parts. The signatories appear to obligate themselves conclusively and directly on only two points.

These are, first, that ". . . the international petroleum trade in all 
its aspects should be conducted in an orderly manner on a world-wide basis with due regard to the considerations set forth in the preamble, and within the framework of applicable laws and concession contracts." The reader is left to search the text and his experience for the meaning of this; it seems to be merely a guarded renunciation by the participants of any intention to create disorder or disturb each other's position.

And second, the signatories agree to propose "to the governments of all interested producing and consuming countries the negotiation of an international oil agreement which also would establish a permanent international council"; and in the meanwhile to set up an American-British commission to deal with numerous problems "of joint immediate interest."

For the rest the agreement consists merely of an impressive but indirect affirmation of selected principles. The phrases in which these principles are expressed are so safeguarded and their exposition so intertwined that it is impossible to decide whether in practice they would prove to be merely new language for the defense of national rights or a new basis of international compromise. The signatory governments promise that they will "direct their efforts" to secure the effective observance of these principles by parties unnamed-presumably the oil companies and governments that they can influence or control.

The principles endorsed are a bid for acceptance of enlightened leadership. They are an attempt to provide a basis for the management of various types of difficulties over oil that have troubled international relations.

The first difficulty of which cognizance is taken arises from the fact that most countries are dependent for their oil on external sources of supply. This has sometimes caused fear and resentment. The dependent countries are subject to anxiety over the possibility of lacking supplies or having to pay more for them than others.

The agreement attempts to quiet this anxiety, during peace time at least. It affirms that oil should be accessible in international trade to all countries on a "competitive and non-discriminatory basis." This is a pledge that dependent nations will not be exploited. It is not, however, an unqualified pledge of basic equality of position. Countries having oil within their own territories would retain the right to reserve it for their own use. Individual companies, operating anywhere, would presumably still be able to reserve their own production for sale through their own distributing facilities; they would not be required to offer their production for sale to all possible buyers, a matter of little significance as long as there is active international competition for oil markets.

Faithful observance of the declared principle would extend and strengthen the practices of commercial equality; it would lessen the 
chance that dependent countries would have to pay excessive prices for oil because of monopoly, marketing arrangements or the pressure of foreign governments. But it would not place all countries in a position of equality in the event of shortage or war. Nor would it change the economic fact that some countries would have to continue to pay for their imported supplies wholly with foreign currencies while other countries would not need to.

The second difficulty taken into account is the suspicion of oil companies that rival foreign interests are conspiring to injure them. Sometimes these suspicions have had no justification, sometimes little, sometimes much. These are imparted to and shared by governments. They generate mistrust and stimulate (or provide a pretext for) the wish to extend political influence over the territories containing the oil.

The signatories affirm their intention to respect each other's valid concession contracts and acquired rights and to refrain from direct or indirect interference with either. If this pledge were honestly observed, relations between the oil interests of different countriesparticularly between those of the United States and Great Britainwould be tranquilized. It would lessen the likelihood of political crises connected with the protection of oil rights.

Thirdly, the agreement takes heed of the struggle between oil interests for the acquisition of new exploration and development rights. It recognizes that groups (sometimes entirely on their own and sometimes aided by their governments) have tried to secure exclusive rights over large fields or areas. The pattern of controversy over this question was drawn in a vigorous contest with Great Britain and the Netherlands in the early twenties to prevent what was judged by American interests to be a deliberate plan to exclude them from many oil-bearing areas. More recently there have been many similar under-cover disputes about opportunities in the Middle East.

The agreement would obligate its signatories so to direct their efforts that "with regard to the acquisition and exploration and development rights the principle of equal opportunity shall be respected." This pledge, even if staunchly upheld, would be a starting point, but little more, for the settlement of disputed situations. Would it mean that the signatories must compel their nationals to refuse a grant of exclusive opportunity freely offered? Would it mean that they would have to join in persuading another country to admit into its territorieseven though it might not wish to do so-the oil enterprise of a country that it fears? Would it mean that if the interests of one country are in a position to out-bid those of another for the whole of an oil opportunity that there must still be a division? Or is it intended rather to favor a division of opportunity among different countries to enter into oil development somewhere in the world rather than in each and every area? Should countries already controlling large resources hold back in their attempts to acquire additional ones? 
These questions illustrate the difficulties of interpretation in applying the principle of equal opportunity. Yet importance attaches to its affirmation at this time. It could be the doctrinal preparation for compromise and moderation on the part of each and every country in its search for oil reserves.

It should be observed in this connection that the signatory governments would not be obligated under the agreement to permit foreign interests to develop oil within their own territories. The right to maintain a closed door is left undisturbed. The theory of equality of opportunity begins abroad and not at home. This limitation, it may be surmised, might be given up by the United States and Great Britain were other countries willing to do likewise. But how many countries are ready to obligate themselves by international agreement to grant foreign enterprise equal rights with their own nationals to develop and sell oil within their borders? The ideas of many seem to be turned the other way.

The fourth main problem considered in the agreement is the fear of countries that grant concessions to foreign groups that they may be unfairly exploited. Nations are easily incited to the belief that they are being cheated by foreign interests, and oil companies seek large profits to offset large outlays and risks. At present a mutually acceptable basis seems to have been found between the large oil companies engaged in foreign operations and the local gorernments with which they deal. There are no grave outstanding disputes in this field. But with the tides of nationalism running strong such disputes may recur. The general principle expressed in the agreement suggests the possible development of an international standard of judgment of rights and obligations.

The agreement, in short, is little more than a treatise on policy. Perhaps this is all that any refotiators could have acconrilished at tlie tin:e. They had to recognize that half a hundred countries would ultimately be concerned in one way or another with the rules that were formulated, and knowledge of what might be generally acceptable was lacking. An invitation to further discussion may have seemed to be the advisable limit of effort. Then, too, as already obserred, the American representatives were in the dark in regard to the extent to which the American government could give effect to any obligation it might assume. Finally, there was no clear prospect of prolonged peace to embolden and encourage. The negotiators came together as spolkesmen for countries which still believed that they had to rely primarily on their own strength and strategy for defense, and on close bargaining for fair economic opportunity. They wanted to avoid disputes over

1. The text of the agreement, as it appeared in (1945) 13 DEP'r of STATE Burc. 481, is printed as an Appendix to this article. 
oil and wished all nations to benefit by their action, but they were not prepared to take any strategic risks, or lessen any acquired advantage.

An attempt to foresee how this treatise on policy would operate in practice is handicapped by uncertainty as to the import of the clause in Article I which makes its constituent elements (the group of affirmed principles) "subject always to considerations of military security. . . ."

Would this mean that each national government would consider itself free to influence or dictate the policies of oil enterprises under its control whenever it seemed important to do so? Governments have not agreed upon international control of any branch of military preparation, nor have they as yet devised any international arrangement for the enforcement of peace to which each is prepared to trust its safety and its destiny. And oil in wartime is a military weapon of primary importance. Therefore it was hardly to be expected that the American and British governments would in this preliminary accord restrict their right to use the oil resources they controlled to the best military advantage. But as long as the reservation is there, rivalry between countries for control of oil supply is likely to continue, no matter how satisfactory the other principles affirmed may prove to be. The needs of military security are elastic, and each government applies its own measuring stick.

Such in brief summary are the main principles that the American and British governments proposed to present to others as a basis for international order in oil. Texts such as this-mere mosaics of principle - may be easily ignored unless some special authority is constituted to keep the nations reminded of their pledge. Furthermore, since the terms of agreement are extremely general, numberless questions of observance, interpretation and application can be foreseen. The ordinary process of discussion between governments will hardly be satisfactory for these purposes.

Therefore the agreement contemplates the establishment of an international petroleum commission. But unfortunately it does not assign to that commission enough authority to assure that its tasks can be effectively performed.

\section{IV}

\section{The International Commissron}

The agreement provides that, pending the negotiation of a general international agreement, the American and British governments would establish a joint commission upon which each would have three members. This commission is assigned only the most tenuous of responsibilities and no power. It is granted the right to consider problems of mutual interest, to study the international petroleum trade and its dislocations, to report on the orderly correlation of supply and demand, and to "make such additional reports as may be appropriate 
for achieving the purpose of this agreement and for the broader general understanding of the problems of the international petroleum trade."

If the signatories insist that the commission confine itself strictly to the duties assigned it would be a licensed source of statistics and of comment, nothing more. It might or might not be permitted also to report-perhaps even to advocate-ideas as well as facts. This would depend on the attitude of its main members and of the oil interests of which they had to take account. Governments are likely to discourage the circulation of recommendations they dislike.

The commission is granted frail permission to strive discreetly through its studies and reports to make the agreement effective. But its members guard themselves against objectionable use of this permission by explicitly providing "that no provision in this agreement shall be construed to require either Government to act upon any report or proposal made by the Commission, or to require the nationals of either Government to comply with any report or proposal made by the Commission, whether or not the report or proposal is approved by that Government."

The provisions regarding the International Petroleum Commission would seem to create no more than a continuously active conference room, attended by a staff of experts and supplied with a multigraph machine. Even this must not be despised or rejected. For such a conference-room might become the birthplace of greater mutual understanding and the home of compromises that would help to preserve the world's peace. But this could only occur in an atmosphere warmed and lighted by a spirit of trust and sense of security among the great powers.

As of this hour, these do not exist. The quarrels, first over Russian activity in Iran, and now over the future of Palestine, have widened every fissure of fear. Each of the three great powers has moved to protect the interest of its nationals in oil against the resistance of the others, and possible disturbance by local rulers or groups. The U.S.S.R. has imposed its demands for concessions upon Iran. Soriet sympathizers and other elements hostile to Britain in the Middle East are hindering-or threatening-the great Anglo-Iranian enterprise. Or so the British government professes as it moves its regiments into new positions in Iraq, and placates the Arabs with the misery of the Zionists. The American government placates Ibn Saud with smallish loans, while it listens attentively to larger proposals for economic development. These events overshadow the attempt to establish an international standard of rights and obligations, an international scheme of order in oil. But they also show that it is essential that the attempt be carried forward. 


\section{APPENDIX}

\section{ANGLO-AMERICAN PETROLEUM AGREEMENT}

- Preamble: The Government of the United States of America and the Government of the United Kingdom of Great Britain and Northern Ireland, whose Nationals hold, to a substantial extent jointly, rights to explore and develop petroleum resources in other countries, recognize:

1. That ample supplies of petroleum, available in international trade to mcet increasing market demands, are essential for both the security and economic well-being of nations;

2. That for the foreseeable future the petroleum resources of the world are adequate to assure the availability of such supplies;

3. That the prosperity and security of all nations require the efficient and orderly development of the international petroleum trade;

4. That the orderly development of the international petroleum trade can best bo promoted by international agreement among all countries interested in the petroleum trade, whether as producers or consumers.

The two Governments have therefore decided, as a preliminary measure to the calling of an international conference to consider the negotiation of a multilateral petroleum agrecment, to conclude the following agreement.

\section{Article I:}

The signatory Governments agree that the international petroleum trade in all its aspects should be conducted in an orderly manner on a worldwide basis with due regard to the considerations set forth in the preamble, and within the framework of applicable laws and concession contracts. To this end and subject always to considerations of military security and to the provisions of such arrangements for the preservation of peace and prevention of aggression as may be in force, the signatory Governments affirm the following general principles with respect to the international petroleum trade:

(A) That adequate supplies of petroleum, which shall in this agreement mean crude petroleum and its derivatives, should be accessible in international trade to the Nationals of all countries on a competitive and nondiscriminatory basis;

(B) That, in making supplies of petroleum thus accessible in international trade, the interests of producing countries should be safeguarded with a view to their economic advancement.

\section{Article II:}

In furtherance of the purposes of this agreement, the signatory Governments will so direct their efforts:

(A) That all valid concession contracts and lawfully acquired rights shall be respected and that there shall be no interference directly or indirectly with such contracts or rights;

(B) That with regard to the acquisition of exploration and development rights the principle of equal opportunity shall be respected;

(C) That the exploration for and development of petroleum resources, the construction and operation of refineries and other facilities, and the distribution of petroleum shall not be hampered by restrictions inconsistent with the purposes of this agreement.

\section{Article III:}

1. With a view to the wider adoption of the principles embodied in this agreement, the signatory governments agree that as soon as practicable they will propose to the governments of all interested producing and consuming countries the negotiation of an international petroleum agreement which inter-alia would establish a permanent international petroleum council.

2. To this end the signatory governments agree to formulate at an early date plans for an international conference to negotiate such a multilateral petroleum agreement. They 
will consult together and with other interested governments with a view to taling whatever action is necessary to prepare for the proposed conference.

\section{Article IV:}

1. Numerous problems of joint immediate interest to the signatory governments with respect to the international petroleum trade should be discussed and resolved on a cooperative interim basis if the general petroleum supply situation is not to deteriorate.

2. With this end in view, the signatory governments agree to establish an international petroleum commission to be composed of six members, three members to be appointed immediately by each government. To enable the commission to maintain clese contact with the operations of the petroleum industry, the signatory governments will facilitate full and adequate consultation with their nationals engaged in the petroleum industry.

3. In furtherance of and in accordance with the purposes of this agrcement, the commission shall consider problems of mutual interest to the signatory governments and their nationals, and with a view to the equitable disposition of such problems it shall be charged with the following duties and responsibilities:

(A) to study the problems of the international petroleum trade caused by dislocations resulting from war;

(B) to study past and current trends in the international petroleum trade; trade;

(C) to study the effects of changing technology upon the international petroleum

(D) to prepare periodic estimates of world demands for petroleum and of the cupplies available for meeting the demands, and to report as to means by which such demands and supplies may be correlated so as to further the efficient and orderly conduct of the international petroleum trade;

(E) To make such additional reports as may be appropriate for achieving the purposes of this agreement and for the broader general understanding of the problems of the international petroleum trade.

4. The Commission shall have power to regulate its procedure and shall establich ouch organization as may be necessary to carry out its functions under this agreement. The expenses of the Commission shall be shared equally by the signatory governments.

\section{Article V:}

The signatory governments agree:

(A) That they will seek to obtain the collaboration of the governments of other producing and consuming countries for the realization of the purposes of this agreement, and to consult with such governments in connection with activities of the Commission;

(B) That they will assist in making available to the Commission such information as may be required for the discharge of its function.

\section{Article VI:}

The signatory governments agree:

(A) That the reports of the Commission shall be published unless in any particular case either government decides otherwise;

(B) That no provision in this agreement shall be construed to require either government to act upon any report or proposal made by the Commission, or to require the nationals of either government to comply with any report or proposal made by the Commission, whether or not the report or proposal is approved by that government.

\section{Article VII:}

The signatory governments agree:

(A) That the general purpose of this agreement is to facilitate the orderly development of the international petroleum trade, and that no provision in this agreement, with the exception of Article II, is to be construed as applying to the operation of the domestic petroleum industry within the country of either government; 
(B) That nothing in this agreement shall be construed as impairing or modifying any law or regulation, or the right to enact any law or regulation, relating to the importation of petroleum into the country of either government;

(C) That, for the purposes of this article, the word "country" shall mean

(1) In relation to the Government of the United Kingdom of "Great Britain and Northern Ireland, the United Kingdom, those British colonies, overseas territories, protectorates, protected states, and all mandated territories administered by that govern* ment and

(2) In relation to the Government of the United States of America, the continental United States and all territory under the jurisdiction of the United States, lists of which, as of the date of this agreement, have been exchanged.

\section{Article VIII:}

This agreement shall enter into force upon a date to be agreed upon after each government shall have notified the other of its readiness to bring the agreement into force and shall continue in force until three months after notice of termination has been given by either government or until it is superseded bys the international petroleum agreement contemplated in Article III. 